\title{
Fisioterapia graduko ikasleek desgaitasunekiko dituzten jarrerak unibertsitateko formazioan zehar
}

\section{Attitudes of Physiotherapy Degree Students towards People with Disabilities}

\author{
Ana Saigos ${ }^{1}$, Naiara Ozamiz-Etxebarria ${ }^{2 *}$, \\ Miren Agurtzane Ortiz ${ }^{1}$ \\ ${ }^{1}$ Medikuntza fakultatea, Neurozientziak saila \\ ${ }^{2}$ Bilboko Hezkuntza Fakultatea, Bilakaeraren eta Hezkuntzaren Psikologia saila
}

LABURPENA: Ikerketa honen helburua Euskal Herriko Unibertsitateko Fisioterapia Graduko lehen mailako eta laugarren mailako ikasleek desgaitasuna duten pertsonen aurrean duten jarrera aztertzea eta ebaluatzea izan da. Horretarako, desgaitasuna duten pertsonen aurrean agertzen diren jarrerei buruzko eskala bat erabili da, eta jarreretan eragin dezaketen zenbait faktore ere aztertu dira (adina, sexua eta desgaitasunarekin izandako kontaktua). Analisi estatistikoak burutu ondoren, emaitzek erakutsi dute bai lehen mailako, bai laugarren mailako ikasleek jarrera positiboa dutela. Ikusi da ere adinak eta desgaitasunarekin kontaktua izateak jarrerak hobetzen dituztela. Bestalde, gizonen eta emakumeen jarreren artean ez da ezberdintasun nabarmenik aurkitu.

GAKO-HITZAK: fisioterapia gradua, unibertsitate hezkuntza, formazioa, desgaitasunak, jarrerak.

ABSTRACT: The aim of this study was to analyse and evaluate the attitude of first-and fourth-year physiotherapy students at the University of the Basque Country towards people with disabilities. In order to achieve this objective, a scale of attitudes towards people with disabilities has been used. A series of factors that can influence attitudes (age, gender and contact with people with disabilities) has also been measured. Statistical analyses were carried out and the results showed that first and fourth year students have a positive attitude. Several factors have also been found to positively influence attitude (age and contact with people with disabilities). On the other hand, no significant differences were found in attitudes between men and women.

KEYWORDS: degree in Physiotherapy, university education, training, disabilities, attitudes.

* Harremanetan jartzeko / Corresponding author: Naiara Ozammiz-Etxebarraia. Euskal Herriko Unibertsitatea. Bilboko Hezkuntza Fakultatea. Bilakaeraren eta Hezkuntzaren Psikologia Saila. Sarriena auzoa 48940. Leioa, Bizkaia. - naiara.ozamiz@ehu.eus - https://orcid.org/0000-0003-4594-1480

Nola aipatu / How to cite: Saigos, Ana; Ozamiz-Etxebarria, Naiara; Ortiz, Miren Agurtzane (2020). «Fisioterapia graduko ikasleek desgaitasunekiko dituzten jarrerak unibertsitateko formazioan zeharn. Tantak, 32(2), 33-50. (https://doi.org/10.1387/tantak.21272).

Jasotze-data: 2019/12/03; Onartze-data: 2020/06/09

ISSN 0214-9753 - elSSN 2444-3581 / (c) 2020 UPV/EHU

(c) (i) Obra hau Creative Commons Atribución 4.0 Internacional-en lizentziapean dago 


\section{SARRERA}

Osasunaren Mundu Erakundearen (OME) arabera, desgaitasuna «termino generikoa da, urritasunetarako, jardueren mugetarako eta parte-hartzearen murrizketetarako» erabiltzen dena. Pertsona batek bere osasun egoeraren ondorioz paira dezakeen kondizioa da desgaitasuna. Urritasunek egituran eta gorputz funtzioan dute eragina. Jardueretarako mugak, aldiz, ekintzak edo betebeharrak burutzeko zailtasunak dira. Bestalde, parte-hartzearen murrizketen barnean, egunerokotasuneko gertakizunetan inplikatzeko arazoak sartzen dira. Beraz, desgaitasuna fenomeno konplexua da, giza organismoaren ezaugarrien eta bizi den gizartearen arteko interakzioan islatzen dena. Estimatzen da munduan mila milioi pertsona baino gehiago bizi direla desgaitasun mota batekin, gutxi gorabehera munduko biztanleriaren \% 15 (OME, 2011). Hainbat erakundek ematen dituzten datu eta ikerketen arabera (Espainiako Imsersoko Ikerketa eta Estatistika Zerbitzua - «Servicio de Estudios y Estadísticas del Imserso»-, Estatistika Institutu Nazionala - «Instituto Nacional de Estadística» - eta ONCE -Cecilia Esparza Catalán, 2011-) Espainian 3528221 pertsona daude desgaitasun egoera batean. Euskadin biztanleriaren \% 8.1ek (172 857 pertsona) eguneroko bizitzako jardueretarako desgaitasun edo mugaren bat duela aitortu du. \% 66.1 emakumeak dira eta gainontzeko \% 33.9, gizonezkoak. Adina aztertzen badugu, \% 68.7k 65 urte baino gehiago dauzka; $\%$ 24.6, 16 eta 64 urte artean daude; \% 2.8, 6 eta 15 urte artean, eta \% 3.8k 6 urte baino gutxiago dauzka.

\subsection{Desgaitasunaren iturriak}

Desgaitasuna eragin dezaketen arrazoiak ugari dira. Egun, munduko populazioaren $4 / 5$ herrialde garatuetan bizi da, eta herrialde horietan gaixotasun ez infekziosoak pairatzen dituzten norbanakoen kopurua handitzen ari da. Gaixotasun horiek, izan ere, desgaitasuna eta hilkortasun goiztiarra eragin dezaketen kausa nagusien artean kokatzen dira (Murray \& Lopez, 1996). Horien artean aurkitzen ditugu depresioa eta bihotzeko gaixotasunak, besteak beste. Zahartzea desgaitasunarekin lotu behar dugun fenomeno nagusietarikoa dugu. Munduko populazioaren zahartzea errealitate bat da, eta adineko pertsonak osasun arazo gehien dituen populazioa da. Harvardeko osasun publikoko eskolak eta Osasunaren Mundu Erakundeak mundu osoko hilkortasunaren eta desgaitasunaren patroiak aztertu zituzten. Ondoren, honako datu hauek aurkitu zituzten: desgaitasun larrienak eragiten dituzten afekzio medikoen artean gaixotasun mentalak (psikosi aktiboa, dementzia, migraina larriak, depresioa), orno-muineko lesioak (tetraplegia, paraplegia) eta ikusmen arazoak (itsutasuna) aurkitu zituzten. 1990ean, bestalde, desgaitasun eragile nagusien artean erorketak, alkoholaren neurri- 
Fisioterapia graduko ikasleek desgaitasunekiko dituzten jarrerak ...

gabekeria eta anemia zeudela zehaztu zuten (Murray \& Lopez, 1996). Era berean, Italian eginiko ikerketa batean gaixotasun neurologikoak desgaitasuna eragiten duten kausen artean aurreneko postuetan kokatu zituzten (Raggi et al., 2015).

\section{2. desgaitasunekiko jarrerak osasuneko profesionalen artean}

Desgaitasun fisikoak dituzten pertsonen osasun-zainketak eta maneiua konplexutasun handiko ekintzak dira. Horrenbestez, ikergai garrantzitsua da herrialde garatuentzat (Satchidanand et al., 2012). Era berean, desgaitasuna duten pertsonekiko jarrera eta uste negatiboak aztertzeko beharra dago, eragin handia baitute pertsona-talde horren inklusio eta integrazio osoa lortzeko (Polo Sánchez, Fernández Jiménez, \& Díaz Batanero, 2011). Beraz, arrazoi horrengatik, ezinbestekoa da jarrera horiek ezagutzea eta ebaluatzea. Horri esker, hainbat garapen programa sortu ahal izango dira jarrera aldaketak gauzatzeko (Antonio León Aguado Díaz, García, \& Rodriguez, 2004; Antonio León Aguado Díaz, Rodríguez, \& Martínez, 2008).

Ikusi da unibertsitateko formazioan zehar desgaitasunari buruz jasotako informazioak eragina duela norbanakoaren jarreretan (Carberry, Waxman, \& McKain, 1981). Bestalde, desgaitasuna duten pertsonek errehabilitazio saioak behar izaten dituzte, eta saio horietan diziplina anitzeko lantaldearekin topo egiten dute: erizainak, fisioterapeutak, terapia okupazionaleko langileak eta errehabilitazioko laguntzaileak, beste batzuen artean. Funtsezkoa da, hortaz, haien zaintzan parte hartzen duten profesionalen lan egiteko era egokia izatea, eta pazienteek behar duten arreta eta tratamendua jasotzea. Hori dela eta, osasun-arloko langileek desgaitasuna duten pazienteekiko dituzten jarrerak ezagutzea garrantzitsua da (Satchidanand et al., 2012).

\subsection{Desgaitasuna unibertsitateko fisioterapia ikasleen artean}

Errehabilitazio saioetan, beraz, pazienteak fisioterapiako profesionalekin topatuko dira. Horrenbestez, langileriaren jarrerak lagungarriak izatea komeni da, tratamendu saioetan eragin positiboa izan dezaten. Jarrera horiek ikasle garaian nolakoak diren ezagutzeak informazio handia ematen du. Esaterako, baliagarria litzateke ikasleen jarrera aldatzeko orduan unibertsitateko ikasketa-programa eraginkorra den jakiteko. Etorkizuneko profesionalak baitira ikasleak. Erabilgarria da, orobat, unibertsitate programak garaiz aldatzeko, beharrezkoa baldin bada.

Munduko herrialde ugaritan hainbat ikerketa egin dira fisioterapiako ikasleek dituzten jarrerei buruz, eta kulturak pentsamolde horietan duen eraginari buruz (Al-Abdulwahab \& Al-Gain, 2003; Robey et al., 2013). Era berean, ezaguna da desgaitasuna duten pertsonekin kontaktua izateak 
ere jarrera positiboak bultzatzen dituela (Gómez \& Infante, 2004; Moreno, Rodríguez, Saldaña, \& Aguilera, 2006; Rimmerman, Hozmi, \& Duvdevany, 2000). Izan ere, desgaitasuna duten pertsonekin lan-esperientziak izateak fisioterapia ikasleen jarrerak positiboago bilakatzen ditu, esperientzia horiek izan ez dituztenekin alderatuta (Stachura \& Garven, 2003; Kay Stachura \& Garven, 2007). Aurkitu izan da, orobat, populazio orokorra aintzat hartuta, unibertsitarioek populazio orokorrak baino jarrera positiboagoak azalaratzen dituztela desgaitasun intelektuala dutenen aurrean (Yazbeck, McVilly \& R.Parmenter, 2004). Gainera, datu hori erlazionatuta dago desgaitasuna duten pertsonekin izandako kontaktuaren iraupenarekin. Desgaitasuna duten pertsonekin kontaktuan egondako aldiak eta haien iraupenak ezinbestekoak izan daitezke aldaketa positiboak bultzatzeko (McConkey \& Truesdale, 2000; Rimmerman et al., 2000). Adibidez, ikerketa baten arabera, jarrera aldaketa bat gertatu zen lau hilabetez desgaitasun neurologikoa (Down sindromea, kasu) duen pertsonaren tutore izandako fisioterapia ikasleengan (Rimmerman et al., 2000). Halaber, desgaitasunarekin kontaktua duten ikasle eta profesionalek jarrera positiboagoak erakusten dituzte haienganako (Au \& Man, 2006). Ikusi da errealitate horrek erlazioa duela langile talde horrek desgaitasunarekin duen kontaktutaren maiztasun altuarekin eta ikasketa maila altuarekin (Olson \& Zanna, 1993).

\subsubsection{Hainbat ikerketa munduko herrialdeetan zehar}

Malawiko Unibertsitateko Medikuntza eskolan fisioterapia ikasketa-programako ikasleek desgaitasunari buruz zituzten iritzi, ikuspuntu eta pentsamoldeak aztertu ziren (Amosun, Kambalametore, Maart \& Ferguson, 2013). 23 ikaslek osatu zuten ikerketa. Hainbat esaldi proposatu zitzaizkien ikasleei, eta esaldi haienganako adostasuna zein desadostasuna adierazi behar zuten. Esaldiek desgaitasunaren munduko zenbait errealitate adierazten zituzten: desgaitasunekin eta ingurugiroarekin erlazionatutakoak, desgaitasuna eta familia, desgaitasuna duten pertsonei gizarteak emandako eskubide zein ukapenei buruzkoak, eta haien gaitasun eta ahalmenei buruzkoak ere. Ikerketa horren aurkikuntzek pentsamolde gehienak positiboak zirela islatu zuten, eta enpatiazko jarrerak nagusi zirela ere bai. Parte -hartzaileek azpimarratzen zuten gizarteak desgaitasuna duten pertsonekin duen tratua ez dela justua, eta horrek zailtasunak gehitzen dizkiela. Desgaitasunen bat pairatuta ere, bizi-kalitate ona izan dezaketela iritzi zioten. Entzunak izateko eskubidea zutelako baieztapenarekin ere ados zeuden. Modu berean, sozializatzeko gaitasuna zutela onartzen zuten, baita lagunak izatekoa ere. Bestalde, ikasleen ikuspuntutik, agerian jartzen zen hauek bere buruan konfiantza zutela desgaitasuna duen pertsona baten zainketak aurrera eramateko, lortutako datuen arabera. Era berean, pentsatzen zuten desgaitasuna duen norbait ez dela beti independientea. Are gehiago, ez zitzaien 
iruditzen esfortzu ekonomiko handirik egin behar denik desgaitasuna duen pertsona baten kargu egiteko. Hori guztia ikusita, pentsa genezake, ikasleek emandako baieztapenen arabera, beharbada haiek ez dutela guztiz ezagutzen zaintzaileen errealitatea.

Nigeriako hiru unibertsitatetan ere, fisioterapiako ikasleek zituzten jarrerei buruz ikertu zen (Vincent-Onabajo \& Malgwi, 2014). 154 ikaslek ATDP-A eskala bete zuten. Eskala horretan desgaitasunari buruzko jarrerak adierazi zituzten zenbait esaldirekin zuten adostasun mailaren arabera. Ikasleen \% 60.4k jarrera positiboak azaleratu zituen. Jarrera positiboen artean desgaitasuna duten pertsonek inteligentzia, lehiakortasuna, autokonfiantza eta independientzia zituztela ezaugarritzat azpimarratu zuten galdetegian. Horrez gain, atseginak eta afektu banatzailetzat ere hartzen zituzten. Halaber, jarrera negatiboak ere ikusarazi ziren: ezberdinak zirela, ez egokituak, kezka iturri, eta antolamendurako senik ez zutela adierazi zuten. Gainera, sentiberagoak eta lotsatiagoak zirela ere zehaztu zuten. Osasunaz gehiago arduratzen diren pertsonak bezala ere ikusten zituzten, desgaitasunaren larritasuna handiagoa den heinean, gehiago arduratzen direla esanez. Bestalde, adina kontuan hartuta, desberdintasun nabariak agertzen ziren jarreretan; horrela, adin gehiagoko ikasleek jarrera positiboagoak adierazi zituzten. Gizon eta emakumeen artean ez zen ezberdintasunik ikusi emaitzetan.

Kanadako Albertako Unibertsitatean ere ATDP-A eskala bete zuten bertako fisioterapia graduko ikasleek (Vargo \& Semple, 1988). Kasu horretan, parte hartu zuten 40 ikasleetatik 37 emakumeak ziren. Ikasle guztiak graduko laugarren kurtsoan zeuden (20-35 urte artekoak). Emaitzen arabera, orokorrean, jarrera positiboa zuten desgaitasunaren aurrean; bai eremu profesionalean, bai pertsonalean.

Mexikon egindako beste ikerketa batean, hango hiru herritan, desgaitasunari buruzko iritziak jaso zituzten bi eskala desberdin erabiliz (García Lara \& Hernandez Ortiz, 2011). Horietako bat Verdugo, Jenaro eta Ariasek 1994an argitaratu zuten desgaitasuna duten pertsonekiko jarrerei buruzko eskala zen (Moreno et al., 2006). Ikerketako parte-hartzaileen \% 42.4k desgaitasuna zuten pertsonekin kontaktua izan zuen. Emaitzen arabera, jarrera positiboenak jaso ziren desgaitasuna duten pertsonen gaitasunen, mugen eta pertsona horiek dituzten nortasun ezaugarriei buruzko itemetan. Halaber, emakume eta gizonen artean ez zen ia ezberdintasunik aurkitu erantzunetan. Jarrera positiboenak honako parte-hartzaile hauengan ikusi ziren: maila altuko ikasketak zituztenak, gazteagoak zirenak, hiriguneetako jendea, ezkonduak, familian desgaitasuna duen norbait ez zutenak, desgaitasun fisiko edo anizkoitza duen norbait ezagutzen zutenak eta noizbehinkako kontaktua izan zutenak.

Era berean, 2010eko ikerketa batean (Shields, Bruder, Taylor \& Angelo, 2010), fisioterapiako ikasleen ikuspuntuak aztertu zituzten, kasu honetan Down sindromea duten pertsonen gaitasunei buruz. Ikerketa horretan 
ikasleak bi taldetan banatu zituzten. Talde bateko ikasleak Down sindromea zuten pertsonen tutore izan ziren 10 astez, ariketa fisikoko programak burutu bitartean. Beste taldeko kideek ariketa fisikoko programa burutu zuten inolako tutoretza lanik gabe. Pertsona haiekin emandako denbora eta jarrera positiboak zuzenki erlazionatuta daudela ikusi zuten.

Orain arte ez da egon Leioako UPV/EHU unibertsitateko fisioterapiako ikasleen jarrera aztertzen duen ikerketarik; beraz, honako ikerketa hau berritzailea da zentzu horretan. Beste arrazoien artean, izan daiteke gradu-eskaintza hori sortu berria izateagatik, ikasle belaunaldi gutxi izan baitira egun arte. Garrantzitsua da jarreretan eragina duten aldagaiak ezagutzea (Aguado Díaz et al., 2008; 2004), informazio horren bidez unibertsitate graduko eskaintzan txerta daitezkeen esku-hartze planak garatzeko. Eta, azkenik, ikerketa honen helburuetariko bat ere ondo formatutako profesionalak lortzea da.

\section{HELBURUAK ETA HIPOTESIA}

\subsection{Helburuak}

Ikerketa honen helburua Euskal Herriko Unibertsitateko ikasleen jarrerak ezagutu eta aztertzea izango da. Horren bidez, baloratu ahal izango dugu unibertsitateko graduak eta han jasotako hezkuntzak jarreretan duen eragina eta, bide batez, profesional bikainak sortzeko ahalmena duen. Jakin ahal izango dugu ikasleek zein behar islatzen dituzten, desgaitasunari buruz duten ikuspuntua egokia izan dadin. Azkenik, graduan beharrizan horiek txertatzea proposatu ahal izango dugu.

\subsection{Hipotesiak}

Sarreran aipatutako aurrekariak kontuan hartuta, honako hipotesi hauek proposatzen dira:

- Ikerketan parte hartuko duten ikasleen jarrera positiboa izango da, bai lehen mailakoena eta baita laugarren mailakoena ere.

- Adinak eragina du jarreren izatasunean. Hain zuzen ere, adin gehiagoko parte-hartzaileen jarrera positiboagoa izango da.

- Modu berean, laugarren mailakoen emaitzetan jarrera positiboagoa islatuko da lehen mailakoenekin konparatuta.

- Neska eta mutilen artean ez da ezberdintasun handirik aurkituko emaitzetan.

- Desgaitasunarekin kontaktuak izateak jarreren joera positiboagoa eragingo du. 


\section{MATERIALAK ETA METODOAK}

\subsection{Subjektuak}

Parte-hartzaileak Euskal Herriko Unibertsitateko (UPV/EHU) ikasleak dira, Medikuntza eta Erizaintza Fakultateko Fisioterapia Graduko lehen eta laugarren kurtsokoak. Bi taldetan banatzen dira datuen azterketarako. Banaketa ez da ausaz egiten, ikasleen bizi-esperientziaren arabera baizik: lehen kurtsoa egiten ari diren ikasleek lehen taldea osatzen dute eta laugarren kurtsoko ikasleek, bigarren taldea.

\subsection{Materialak}

\subsubsection{Baimen informatua}

Baimen informatu bat idatzi zen ikasleek ikerketan parte har zezaten. Baimen informatuan ikasleei ikerketaren nolakotasunei buruzko informazioa eman zitzaien: ikerketaren helburua, ikerketaren prozedura, parte-hartzearen onura eta arriskuak eta datuen konfidentzialtasunaren bermea. Sinatzearekin batera, ikerketan parte hartuko zutela baieztatzen zuten. Prozesua Etikako Batzordeak onartuta zegoen, beti ere Medikuen Mundu Elkarteak Helsinkiko Deklarazioan eskainitako gomendioak errespetatuz.

\subsubsection{Desgaitasuna duten pertsonen aurrean agertzen diren jarrerei buruzko eskala}

Eskala honen bidez edozein motatako desgaitasunaren aurrean norbanakoak izan ditzakeen jarrerak ebaluatzen dira. Verdugo, Jenaro \& Ariasek 1994an egituratu zuten. Eskala multidimentsionala da, Espainian sortutakoa eta gaztelerazko formatuan. Domínguez Larak gauzatutako lanean (Domínguez Lara, 2013) ere erabili zen, eta eskalaren propietate psikometrikoak aztertu zituzten bertan, haren baliozkotasuna baieztatzeko. Fidagarritasun azterketak pasatu ditu (alfa de Cronbach .92), eta eskalaren fidagarritasuna $0.8597 \mathrm{koa}$ da.

Galdeketa beteko duen pertsonak bere iritzia eman behar du, bertan agertzen diren esaldiekin ados dagoen ala ez adieraziz.

Eskalak dimentsio ezberdinak aztertzen ditu, hala nola desgaitasuna duten pertsonen ahalmen eta mugei buruzkoak, eskubideen aitorpen edo ezeztapenei buruzkoak, desgaitasunen bat duenarekin erlazionatzean izango lukeen jokabide zehatzei buruzkoak, desgaitasuna duten pertsonek fenomeno hori pairatzeagatik duten ustezko nortasun ezaugarri eta haiek dituzten jokamoldeei buruzkoak. 
Eskala 37 itemez osatuta dago, eta 5 azpigaitan banatuta daude. Jarraian azpigai edo dimentsio desberdinak osatzen dituzten itemak ikusiko ditugu:

- Gaitasun eta mugen balorazioa: 1, 2, 4, 7, 8, 13, 16, 21, 29 eta 36.

- Eskubideen onarpen/ezeztapena: 6, 9, 12, 14, 15, 17, 22, 23, 27, 35 eta 37.

- Inplikazio pertsonala: 3, 5, 10, 11, 25, 26 eta 31 .

- Kalifikazio generikoa: 18, 20, 24, 28 eta 34 .

- Rolen egokitzea: 19, 30, 32 eta 33.

Jarrerak positibotzat edo negatibotzat, nola jotzen diren, itemak 2 azpitaldetan sailkatzen dira:

- Jarrera positiboak adierazten dituzten itemak: 3, 9, 11, 12, 13, 14, $16,19,20,21,22,27,30,32,33$ eta 36 .

- Jarrera negatiboak adierazten dituzten itemak: 1, 2, 4, 5, 6, 7, 8, 10, $15,17,18,23,24,25,26,28,29,31,34,35$ eta 37.

Datu pertsonalak haintzat hartzen dira: adina, sexua, graduko zein kurtsotan dauden, baita kontakturik izan ote duten desgaitasunik duten pertsonekin (formato itxian erantzunda: BAI/EZ).

Baiezko kasuetan, kontaktuari buruzko ezaugarri kualitatiboak zehaztu behar dituzte: kontaktuaren jatorria (senidekoa, laborala, asistentziala, lagunarte/aisialdikoa edo beste jatorriren bat), kontaktuaren maiztasuna (oso ohikoa, sarritan, gutxitan, ia inoiz ez), kontaktuaren kalitatea (oso positiboa, positiboa, neutroa, negatiboa eta oso negatiboa) eta desgaitasun mota (fisikoa, entzumenekoa, ikusmenekoa, atzerapen mentala eta anizkoitza).

\subsection{Metodoak}

Parte-hartzaileek desgaitasuna duten pertsonekiko jarrerei buruzko eskala bete behar zuten. Bi taldetan banatu ziren: horrela, Fisioterapia graduko lehen kurtsoko ikasle guztiek lehenengo taldea osatzen dute, eta laugarren kurtsoan matrikulatutakoek bigarren taldea osatzen dute. Parte-hartzaileek baimen informatua irakurri eta sinatu behar zuten ikerketan sartu aurretik. Baimen informatua onartu ostean, galdetegia betetzeko aukera ematen zitzaien. Galdetegiak eta baimen informatuak ikertzaile baten eskutik banatu ziren, eta nola bete behar zuten azaldu zitzaien ikasleei. Zalantzarik izanez gero, bertan argitu zitzaien. Galdetegiak praktika-klase orduetatik kanpo bete zituzten, Fakultatean.

\subsubsection{Analisi estatistikoak}

Datu base bat egin zen MS Excel ordenagailu programan modu antolatu eta errazean egiteko galdetegietako emaitzen analisia. Jarrera ne- 
gatiboak adierazten zituzten itemen puntuazioa alderantzizkatu zen item guztiek norabide berera jotzeko eta puntuazio maximo batek jarrera positiboagoa erakusteko. Puntuazioak 1etik 6ra zehaztu ziren, eta galdetegiko erantzun bakoitzari zenbaki bat egokitu zitzaion, adostasun mailaren arabera ordenatuta. 6ko puntuaziotik gertuago egoteak jarrera positiboagoa adierazten du. Analisi estatistikoa R Comamander ordengailu programaren bidez gauzatu zen Excel orrietatik informazioa inportatu ostean. Eskalaren azpigaietan subjektu taldeek jasotako batezbestekoak jaso eta korrelazioak atera ziren.

Ikasturtea, desgaitasunarekin izandako kontaktua eta sexua izendatu ziren aldagaitzat. Konparaketak egiteko «t» analisia erabili zen.

Batezbestekoen arteko konparazioak egiteko eta emaitzen esangura estadistikoa zehazteko, p-aren balioa 0,05 baino txikiagoa izatea aukeratu zen.

Datuak baremoekin kontrastatu ziren (Dominguez L. et al., 2013), ezaugarri soziodemografiko bereko populazio orokorrarekin konparatu ahal izateko eta kokatzeko.

\section{EMAITZAK}

Fisioterapia graduko lehen kurtsoko 42 ikaslek eta laugarren kurtsoko $32 \mathrm{k}$ parte hartu zuten.

Lehen eta bigarren taulan ikus daitezke talde bakoitzeko taldekideen ezaugarriak (sexua eta adina) eta talde bakoitzaren homogeneitatea.

\section{1. taula}

\section{UPV/EHUko Fisioterapia Graduko lehen mailako ikasleen ezaugarri soziodemografikoak}

\begin{tabular}{ccclcc}
\hline Adina & Kopurua & Portzentajeak & \multicolumn{1}{c}{ Sexua } & Kopurua & Portzentajeak \\
\hline 18 & 26 & $\% 62$ & Emakumea & 28 & $\% 67$ \\
19 & 9 & $\% 21$ & Gizona & 10 & $\% 24$ \\
20 & 2 & $\% 5$ & Erantzun gabe & 4 & $\% 9$ \\
21 & 3 & $\% 7$ & & & \\
Erantzun gabe & 2 & $\% 5$ & & \\
Batezbestekoa & $18.55 \pm 0.9$ & & & \\
\hline Guztira & 42 & Guztira & 42 \\
\hline
\end{tabular}


Ana Saigos, Naiara Ozamiz-Etxebarria, Miren Agurtzane Ortiz

2. taula

UPV/EHUko Fisioterapia Graduko laugarren mailako ikasleen ezaugarri soziodemografikoak

\begin{tabular}{ccclcc}
\hline Adina & Kopurua & Portzentajeak & \multicolumn{1}{c}{ Sexua } & Kopurua & Portzentajeak \\
\hline 21 & 26 & $\% 81$ & Emakumea & 23 & $\% 72$ \\
22 & 3 & $\% 10$ & Gizona & 9 & $\% 28$ \\
23 & 2 & $\% 6$ & Erantzun gabe & 0 & $\% 0$ \\
45 & 1 & $\% 3$ & & & \\
Erantzun gabe & 0 & $\% 0$ & & & \\
Batezbestekoa & $21.97 \pm 4.24$ & & & & \\
\hline Guztira & 32 & & Guztira & 32 & \\
\hline
\end{tabular}

Hirugarren taulan agertzen den moduan, eskalaren azpigai ezberdinen batezbestekoen artean ez dago ezberdintasun esanguratsurik ( $\mathrm{p}$ value $=>0.05$ ). Hala ere, bi taldeen batezbestekoen balioak ikusita baiezta daiteke laugarren mailari dagokion taldeak puntuazio altuagoak lortu dituela eskalaren azpigai guztietan. Bestalde, eskubideen onarpen/ezeztapen eta inplikazio pertsonalari buruzko azpigaietan gertatu dira aldaketa nabarienak.

3. taula

Desgaitasuna duten pertsonen aurrean ditugun jarrerei buruzko eskalaren azpigai ezberdinetan jasotako batezbestekoen arteko konparazioak

\begin{tabular}{|c|c|c|c|c|c|}
\hline \multirow[b]{2}{*}{ Eskalaren azpigaiak } & \multicolumn{2}{|c|}{ B.B. } & \multirow[b]{2}{*}{$\mathrm{p}$ value } & \multicolumn{2}{|c|}{$\mathrm{Pc}$} \\
\hline & $\begin{array}{c}1 . \\
\text { Maila }\end{array}$ & $\begin{array}{c}4 . \\
\text { Maila }\end{array}$ & & $\begin{array}{c}1 . \\
\text { Maila }\end{array}$ & $\begin{array}{c}4 . \\
\text { Maila }\end{array}$ \\
\hline Gaitasun eta mugen balorazioa & $49.45 \pm 6.79$ & $51.19 \pm 5.04$ & 0.2111 & 80 & 85 \\
\hline Eskubideen onarpen/ezeztapena & $60.81 \pm 6.02$ & $62.31 \pm 3.50$ & 0.1829 & 60 & 75 \\
\hline Inplikazio pertsonala & $39.31 \pm 3.87$ & $40.31 \pm 2.30$ & 0.1688 & 75 & 80 \\
\hline Kalifikazio generikoa & $23.76 \pm 4.18$ & $24.09 \pm 2.97$ & 0.6908 & 75 & 80 \\
\hline Rolen egokitzea & $18.12 \pm 4.09$ & $18.22 \pm 3.50$ & 0.9104 & 40 & 40 \\
\hline TOTALA & 191.45 & 196.12 & Guztira & 80 & 85 \\
\hline
\end{tabular}

Laugarren taulako datuak ikusita ez dago oso argi desgaitasunarekin kontaktuak izatearen eragina. Emaitzak ez dira estatistikoki esanguratsuak ( $p$ value $=>0.05$ ) eta datuek ez dute joera berdina azpigai guztietan. Eskubideen onarpen/ezeztapenean, inplikazio pertsonalean eta kalifikazio generikoan, desgaitasunarekin kontaktua izateak jarrera positiboagoak sortzen 
Fisioterapia graduko ikasleek desgaitasunekiko dituzten jarrerak ...

zituen. Rolen egokitzean, aldiz, jarrera positiboagoak islatzen zituzten desgaitasunarekin kontaktua izan ez dutenek.

4. taula

Desgaitasunarekin kontaktua izatearen arabera eskalaren azpigaietan jasotako datuen batezbestekoak. Aldagai independienteetarako t testa

\begin{tabular}{|c|c|c|c|c|c|}
\hline \multirow{2}{*}{ Eskalaren azpigaiak } & \multicolumn{2}{|c|}{$\begin{array}{c}\text { Desgaitasunarekin } \\
\text { kontaktua (B.B.) }\end{array}$} & \multirow{2}{*}{$\mathrm{p}$ value } & \multicolumn{2}{|c|}{$\mathrm{Pc}$} \\
\hline & Bai & $\mathrm{Ez}$ & & Bai & $\mathrm{Ez}$ \\
\hline Gaitasun eta mugen balorazioa & $50.18 \pm 5.91$ & $50.33 \pm 7.39$ & 0.946 & 85 & 85 \\
\hline Eskubideen onarpen/ezeztapena & $61.40 \pm 5.09$ & $61.75 \pm 5.48$ & 0.8419 & 70 & 70 \\
\hline Inplikazio pertsonala & $39.82 \pm 3.35$ & $39.33 \pm 3.14$ & 0.6319 & 75 & 75 \\
\hline Kalifikazio generikoa & $23.92 \pm 3.79$ & $23.83 \pm 3.24$ & 0.9358 & 75 & 75 \\
\hline Rolen egokitzea & $18.26 \pm 3.81$ & $17.67 \pm 3.94$ & 0.6391 & 40 & 30 \\
\hline
\end{tabular}

Bosgarren taulan, sexuaren arabera, ikasleek azpigaietan eskuratutako puntuazioen batezbestekoak ikus daitezke. Kasu honetan ere datuek ez dute pisu estatistikorik ( $\mathrm{p}$ value $=>0.05$ ). Bestalde, batezbesteko altuagoak lortu dira emakumeen taldean bost azpigaietatik lautan. Hemen ere, Rolen egokitzeari buruzko azpigaiak balio baxuak lortu ditu baremoetan, bai emakumeei zein gizonezkoei dagokienez.

5. taula

Eskalaren azpigaietan eskuratutako puntuazioen batezbestekoak sexuaren arabera. Aldagai independienteetarako t testa

\begin{tabular}{l|cc|c|cc}
\hline \multirow{2}{*}{\multicolumn{1}{c|}{ Eskalaren azpigaiak }} & \multicolumn{2}{|c|}{ Sexua (B.B.) } & \multirow{2}{*}{ p value } & \multicolumn{2}{c}{ Pc } \\
\cline { 2 - 3 } & Emakumea & Gizona & & Emakumea & Gizona \\
\hline Gaitasun eta mugen balorazioa & $50.76 \pm 6.11$ & $49.37 \pm 5.52$ & 0.4244 & 85 & 80 \\
Eskubideen onarpen/ezeztapena & $61.84 \pm 5.25$ & $60.68 \pm 4.97$ & 0.3988 & 70 & 60 \\
Inplikazio pertsonala & $39.94 \pm 3.33$ & $39.74 \pm 2.80$ & 0.7985 & 75 & 75 \\
Kalifikazio generikoa & $23.65 \pm 3.65$ & $24.74 \pm 3.94$ & 0.3026 & 75 & 80 \\
Rolen egokitzea & $18.31 \pm 3.89$ & $18.26 \pm 3.84$ & 0.9614 & 40 & 40 \\
\hline
\end{tabular}

Kurtsoen arabera, desgaitasunarekin izandako kontaktua aztertuz gero, ikus daiteke laugarren mailako ikasleen artean pertsona gehiagok ezagutzen duela desgaitasuna duen norbait. Seigarren taulan ikusten denez, laugarren mailan ikasleen \% 97k eta lehen mailan \% 74k. 


\author{
6. taula
}

Desgaitasunarekin izandako kontaktuari buruzko datuak unibertsitate graduko kurtsotan banatuta

\begin{tabular}{lcc}
\hline \multicolumn{1}{c}{ Desgaitasunarekin kontaktua } & Kopurua & Portzentajeak \\
\hline Lehen maila & & \\
Bai & 31 & $\% 74$ \\
Ez & 11 & $\% 26$ \\
Erantzun gabe & 0 & $\% 0$ \\
Laugarren maila & & $\% 97$ \\
Bai & 31 & $\% 3$ \\
Ez & 1 & $\% 0$ \\
Erantzun gabe & 0 & \\
\hline
\end{tabular}

Zazpigarren taulan agertzen den bezala, esparru sozial intimo eta informaletan desgaitasuna duten pertsonak ezagutzen dituzten ikasleak asko dira. Besteak beste, lehen mailan familiako kideren bat desgaitasunarekin ezagutzen dutenak \% 26 dira, eta lagunartean, \% 21. Laugarren mailan, bestalde, familian desgaitasuna duen norbait ezagutzen dutenak $\% 22$ dira. Argitu behar da ere, ikasle askok hutsik utzi zutela galdetegiko zati hori eta (lehen mailan \% 28k erantzun gabe utzi zuen atala). Aipatzekoa da laugarren mailako ikasleen \% 50ek lan esparruan ezagutu zituela desgaitasuna duten pertsonak.

\title{
7. taula
}

Desgaitasunarekin izandako kontaktua zein esparru sozialetan eman denari buruzko informazioa. Unibertsitate graduko kurtsotan banatuta

\begin{tabular}{lcc|lcc}
\hline \multicolumn{3}{c|}{ Lehen maila } & \multicolumn{3}{c}{ Laugarren maila } \\
\hline Esparru soziala & Kopurua & Portzentajeak & Esparru soziala & Kopurua & Portzentajeak \\
\hline Familia & 11 & $\% 26$ & Familia & 7 & $\% 22$ \\
Lagunartea & 9 & $\% 21$ & Lagunartea & 0 & $\% 0$ \\
Lana & 0 & $\% 0$ & Lana & 16 & $\% 50$ \\
Asistentziala & 2 & $\% 5$ & Asistentziala & 0 & $\% 0$ \\
Anizkoitza & 4 & $\% 10$ & Anizkoitza & 8 & $\% 25$ \\
Erantzun gabe & 12 & $\% 28$ & Erantzun gabe & 1 & $\% 3$ \\
Beste arrazoiak & 4 & $\% 10$ & Beste arrazoiak & 0 & $\% 0$ \\
\hline Guztira & 42 & $\% 100$ & Guztira & 32 & $\% 100$ \\
\hline
\end{tabular}


Lehen mailakoen artean \% 24 da desgaitasun anizkoitzdun pertsonak ezagutzen dituzten ikasleak, eta laugarren mailakoen artean \% 56ra igotzen da kopuru hori. Bestelako desgaitasun motak nahiko banatuta daude, baina bigarren postuan atzerapen mentala eta fisikoak daude. Lehen mailako ikasleen \% 17k desgaitasun intelektuala duen norbait ezagutzen du, eta $\% 14 \mathrm{k}$, desgaitasun fisikoa duen baten bat. Laugarren mailan ikasleen $\% 38 \mathrm{k}$ desgaitasun fisikoa duen norbait ezagutzen duela adierazi du (8. taula).

8. taula

\section{Ikerketako parte-hartzaileek ezagutu dituzten desgaitasun motak}

\begin{tabular}{lcc}
\hline \multicolumn{1}{c}{ Desgaitasun mota } & Kopurua & Portzentajeak \\
\hline Lehen maila & 6 & $\% 14$ \\
Fisikoa & 3 & $\% 7$ \\
Entzumena & 4 & $\% 9$ \\
Ikusmena & 7 & $\% 17$ \\
Atzerapen mentala & 10 & $\% 24$ \\
Anizkoitza & 12 & $\% 29$ \\
Erantzun gabe & 42 & $\% 100$ \\
Guztira & & $\% 38$ \\
Laugarren maila & 12 & $\% 3$ \\
Fisikoa & 1 & $\% 0$ \\
Entzumena & 0 & $\% 56$ \\
Ikusmena & 0 & $\% 3$ \\
Atzerapen mentala & 18 & \\
Anizkoitza & 1 & \\
Erantzun gabe & &
\end{tabular}

Aipatzekoa da orokorrean bi ikasle taldeentzat desgaitasuna duten pertsonekin izandako interakzioari buruzko pertzepzio subjektiboa positiboa izan dela, inork ez baitu adierazi interakzio hori negatiboa edo oso negatiboa izan zenik. Ikusten den bezala, laugarren mailako ikasleen taldean modu adierazgarrian handitzen da kontaktuaren maiztasuna, ikasleen $\%$ 69k ohiko maiztasunez elkartzen baitira kondizio mota honetako pertsonekin. 
Ana Saigos, Naiara Ozamiz-Etxebarria, Miren Agurtzane Ortiz

$$
\text { 9. taula }
$$

Desgaitasunarekin izandako kontaktuari buruzko gainontzeko erantzunen analisi deskriptiboa

\begin{tabular}{lcclcc}
\hline \multicolumn{1}{c}{ Kalitatea } & Kopurua & Portzentajeak & Maiztasuna & Kopurua & Portzentajeak \\
\hline Lehen maila & & & & & \\
Oso positiboa & 16 & $\% 39$ & Oso ohikoa & 10 & $\% 24$ \\
Positiboa & 12 & $\% 28$ & Ohikoa & 11 & $\% 26$ \\
Neutral & 2 & $\% 5$ & Ezohikoa & 8 & $\% 19$ \\
Negatiboa & 0 & $\% 0$ & Ia nulua & 1 & $\% 2$ \\
Oso negatiboa & 0 & $\% 0$ & Erantzun gabe & 12 & $\% 29$ \\
Erantzun gabe & 12 & $\% 28$ & & & \\
Laugarren maila & & & & & \\
Oso positiboa & 8 & $\% 25$ & Oso ohikoa & 6 & $\% 19$ \\
Positiboa & 17 & $\% 53$ & Ohikoa & 22 & $\% 69$ \\
Neutral & 5 & $\% 16$ & Ezohikoa & 2 & $\% 63$ \\
Negatiboa & 0 & $\% 0$ & Ia nulua & 1 & $\% 3$ \\
Oso negatiboa & 0 & $\% 0$ & Erantzun gabe & 1 & $\% 3$ \\
Erantzun gabe & 2 & $\% 6$ & & & \\
\hline
\end{tabular}

\section{EZTABAIDA}

Ikerketa honen helburua Euskal Herriko Unibertsitateko Fisioterapia Graduko ikasleek desgaitasuna duten pertsonekin dituzten jarrerak aztertzea eta deskribatzea zen. Horretarako, zenbait aldagai aztertu dira: desgaitasunarekin izandako kontaktua, ikasturtea eta sexua.

Adieraz daiteke ikasleen jarrerak desgaitasunaren aurrean orokorrean positiboak direla. Berdin ikusi zuten beste hainbat ikerketetan (Amosun et al., 2013; Vargo \& Semple, 1988; Vincent-Onabajo \& Malgwi, 2014; Yazbeck et al., 2004). Bestalde, ikerketa honetako ikasleek argi daukate desgaitasunek ez dituztela soilik mugak ekartzen, eta pertsona horiek gaitasun ugari izan ditzaketela. Emaitza horiek bat datoz Malawin eginiko ikerketarekin (Amosun et al., 2013). Ikerketa horretako ikasleek adierazi zutenez, desgaitasunak bizi-kalitatea ez zuen deuseztatzen. Entzunak izateko eskubidea zutela eta harreman sozialak eta lagunartekoak izateko gaitasuna zutela ere adierazi zuten. Hortaz, esan daiteke ikasleek ez dutela ideia estereotipaturik ezta aurreiritzi negatiborik ere, eta hori islatuko dela desgaitasuna duten pertsonekin harremanak izateko orduan.

Ikerketa askotan ikusi den moduan (Vargo \& Semple, 1988; Vincent-Onabajo \& Malgwi, 2014), adina gora doan heinean jarrera positiboagoa daukate parte-hartzaileek. Ikerketa honetako bi ikasle taldeen artean adin salto bat dago eta hori islatzen da laugarren mailakoen balioetan. Aurkako emaitzak aurkitu ziren, ordea, Mexikon eginiko ikerketan (García Lara \& Hernandez Ortiz, 2011). 
Ikerketa askotan ikusi den bezela (Gómez \& Infante, 2004; Moreno et al., 2006; Rimmerman et al., 2000), kasu honetan ere, desgaitasunarekin kontaktua izateak eragin positiboa du, eta jarrerak aldatzen ditu. Ondorio horretara iritsi ziren Down Sindromedunekin prestatutako ikerketan ere, eta baita osasun profesionalekin eginiko beste ikerketa askotan ere (Au \& Man, 2006; McConkey \& Truesdale, 2000; Olson \& Zanna, 1993; Shields et al., 2010). Era berean, laugarren mailakoei desgaitasunarekin duten kontaktuaren maiztasunari buruz galdetzean, lehen mailakoek baino sarriago interaktuatzen dutela adierazi zuten. Emaitza horiek graduko praktika-orduetan izandako bizi esperientziek justifika ditzakete nolabait. Datu horrek ere baieztatzen digu unibertsitateko praktika-orduetan desgaitasuna duten pertsonekin harremanak dituztela ikasleek. Ondoriozta daiteke ikasleek izandako lan esperientziek eragin izan dutela jarrera positiboak garatzeko orduan, eta bat dator beste autore batzuekin (K Stachura \& Garven, 2003; Kay Stachura \& Garven, 2007).

Ikerketa honetan ere, beste askotan bezala (García Lara \& Hernandez Ortiz, 2011; Satchidanand et al., 2012; Vincent-Onabajo \& Malgwi, 2014), emakume eta gizonen artean aurkitutako ezberdintasunak minimoak eta ez-esanguratsuak dira. Horregatik, sexuaren araberako jarreretan ezberdintasunik ez dagoela igarri daiteke.

Ikerketaren mugei dagokienez, laginaren tamaina aipatu behar da alde batetik. Fisioterapia graduan bi ikasgela besterik ez dago ikasturte bakoitzeko, eta, beraz, zaila da lagin handia lortzea. Hurrengo ikerketetan ikasle gehiagok parte hartzea espero da. Hala ere, esan beharra dago Malawiko Unibertsitateko Medikuntza eskolan egindako ikerketan ere 23 ikaslek parte hartu zutela (Amosun, Kambalametore, Maart \& Ferguson, 2013) eta 40 ikaslek Kanadako Albertako Unibertsitatean (Vargo \& Semple, 1988).

Bestalde, hainbat emaitza ez dira estatistikoki esanguratsuak; beraz, ikerketa gehiago egin beharko lirateke aldagai horien inguruan.

\section{ONDORIOAK}

Ikerketaren emaitzek erantzuna ematen diete hipotesiei. Proposatutako hipotesiak bost izan dira, eta, desgaitasuna duten pertsonekiko jarrerei buruzko eskalaren bidez, emaitza interesgarriak jaso dira.

Lehenik eta behin, Euskal Herriko Unibertsitateko Fisioterapia ikasleen jarrera positiboa izango zela proposatu zen, bai lehen mailakoena, bai laugarren mailakoena. Emaitzek baieztatu dute hipotesi hori. Bi kurtsoen datuak, baremoekin konparatuta, balioak postu altuetan kokatzen dira.

Bigarrenik, adin nagusiko populazioak jarrera positiboagoa duela adierazi da hipotesien artean, eta jasotako emaitzei esker baieztatu da hori.

Hirugarrenik, emaitza horiek ere baliagarriak dira proposatutako hirugarren hipotesia baieztatzeko, laugarren mailakoek lehen mailakoekin konparatuta jarrera positiboagoa dutela, alegia. 
Laugarrenik, bi sexuen artean ezberdintasun minimoak izango zirela proposatu zen ikerketaren hasieran. Emaitzetan agertu denaren arabera, ezberdintasunak egon arren, bi sexuen arteko emaitzetan ez dira estatisitikoki baliagarriak izan; beraz, hipotesia baieztatuko litzateke.

Azkenik, desgaitasunarekin kontaktua izateak jarreren hobekuntza bultzatzen duela aipatu zen hipotesien artean. Emaitzen arabera, desgaitasunarekin kontaktua izan duten ikasleek jarrera positiboagoa islatu dute.

Ikusi den bezala, Euskal Herriko Unibertsitatera etortzen diren ikasleak jarrera positiboarekin sartzen dira. Gradua aurrera doan heinean, errealitate eta ikuspuntu ugari bereganatzen dituzte, beti ere, haien ikuspuntua hobetuz. Beraz, esan daiteke ikasleek desgaitasunari buruz ere ikasten dutela graduan, eta heldutasun maila altuago batekin irteten direla unibertsitatetik. Dena dela, irabaziak ez dira oso altuak eta, beraz, emaitza hauek argitzen digute lan egin daitekeela ikasturte programak hobetzeko. Besteak beste, psikologia mailako zenbait kontzeptu eguneratu ikasiz, kasu kliniko errealak aztertuz, eta baita praktika klinikoan desgaitasun mota anitzak dituzten norbanakoak ezagutzeko aukera emanez ere. Argi dago ezinbestekoa dela desgaitasunarekin kontaktua izatea jarreren aldaketa positiboa gertatzeko. Argitu behar da, hala ere, zailagoa dela abiapuntu hain altu batetik aldaketak lortzea, baina horrek ez du esan nahi ezin denik ezer egin jarrerak are hobeak bilakatzeko. Modu horretara, profesional hobeak lortuko genituzke, eta horrela interbentzio planak egokiak eta zehatzagoak izango lirateke. Alde profesionalaz aparte, alde pertsonala ere landuko litzateke horrela, ikasleek enpatia sentimenduak garatzea lukete. Horrek asko laguntzen baitu norbanakoaren egunerokotasunean bizitzako alderdi sozial guztietan. Profesional bikaina izateko ez baita nahikoa teknika eta metodoak zehatz ezagutu eta erabiltzea, giza harremanak egoki maneiatzea ere garrantzitsua da. Fisioterapeuta baten lana beti izango baita pertsonekin, eta, beraz, pazienteari konfiantza, segurtasuna eta giro atsegina eskaintzeak asko laguntzen du.

\section{ERREFERENTZIAK}

Aguado Díaz, A. L., Alcedo Rodríguez, M. Á., \& Arias Martínez, B. (2008). Cambio de actitudes hacia la discapacidad con escolares de Primaria. Psicothema, 20(4), 697-704. Interneten eskuragarri: http://www.redalyc.org/articulo. oa? id=72720429

Aguado Díaz, A. L., FlórezGarcía, M. Á., \& Alcedo Rodríguez, M. Á. (2004). Programas de cambio de actitudes ante la discapacidad. Psicothema, 16(4), 667-673. Interneten eskuragarri: https://www.unioviedo.es/reunido/index.php/PST/article/ view/8173

Al-Abdulwahab, S. S., \& Al-Gain, S. I. (2003). Attitudes of Saudi Arabian Health Care Professionals Towards People with Physical Disabilities. Asia Pacific Disability Rehabilitation Journal, 14(1), 63-70. Interneten eskuragarri: http:// www.aifo.it/english/disability/apdrj/apdrj103/attitudes-professionals.pdf 
Fisioterapia graduko ikasleek desgaitasunekiko dituzten jarrerak ...

Amosun, S., Kambalametore, S., Maart, S., \& Ferguson, G. (2013). Undergraduate physiotherapy education in Malawi - The views of students on disability. Malawi Medical Journal, 25(2), 40-44. Interneten eskuragarri: https://www. ajol.info/index.php/mmj/article/view/91030

Au, K. W., \& Man, D. W. K. (2006). Attitudes toward people with disabilities: a comparison between health care professionals and students. International Journal of Rehabilitation Reserarch, 29(2), 155-160. https://doi.org/10.1097/01. mrr.0000210048.09668.ab

Carberry, H., Waxman, B., \& McKain, D. (1981). An In-Service Workshop Model for Regular Class Teachers Concerning Mainstreaming of the Learning Disabled Child *. Journal of Learning Disabilities, 14(1). Interneten eskuragarri: http://journals.sagepub.com/doi/abs/10.1177/002221948101400111?journalCo de=ldxa

Cecilia Esparza Catalán. (2011). Discapacidad y dependencia en el País Vasco. Informes Portal Mayores, 125. Interneten eskuragarri: http://envejecimiento. csic.es/documentos/documentos/pm-discapacidad-01.pdf

Dominguez L., S., Villegas, G., Aquije C., D., Castillo C., A., Dulanto M., N., Llontop V., C., \& Rimachi D., M. (2013). Propiedades psicométricas de la Escala de Actitudes hacia las Personas con Discapacidad en una muestra de escolaren de Lima Metropolitana. Revista de Peruana de Psicologia Y Trabajo Social, 2(2), 15-30. Interneten eskuragarri: http://revistas.uigv.edu.pe/index. $\mathrm{php} / \mathrm{psicologia/article/view/3}$

Dominguez Lara, S. (2013). Actitudes hacia las Personas con Discapacidad en una muestra de estudiantes de educación secundaria de Lima. Av. Psicologia, 21(2), 181-193. Interneten eskuragarri: http://www.unife.edu.pe/publicaciones/revistas/psicologia/2013/2/Sergio-Dominguez.pdf

García Lara, G. A., \& Hernandez Ortiz, S. (2011). Actitudes hacia la discapacidad de jóvenes y adultos de Chiapas. Universitas Psychologia, 10(3), 817-827. Interneten eskuragarri: http://web.b.ebscohost.com/ehost/detail/detail?sid=2688286ea641-4a2c-96cc-da3c20b2120b\%40sessionmgr110\&vid=0\&hid=116\&bdata=Jn NpdGU9ZWhvc3QtbG12ZQ\%3D\%3D\#AN=76314796\&db=a9h

Gómez, V., \& Infante, M. (2004). Actitudes de los estudiantes de educación hacia la integración de personas con discapacidad y hacia la educación multicultural. Cultura Y Educación, 16(4), 371-383. https://doi.org/10.1174/1135640042802455

McConkey, R. \& Truesdale, M. (2000). Reactions of nurses and therapists in mainstream health services to contact with people who have learning disabilities. Journal of Advanced Nursing, 32(1), 158-163. https://doi.org/10.1046/ j.1365-2648.2000.01413.x

Moreno, F. J., Rodríguez, I. R., Saldaña, D. \& Aguilera, A. (2006). Actitudes ante la discapacidad en el alumnado universitario matriculado en materias afines. Revista Iberoamericana de Educación, 40, 5-25. Interneten eskuragarri: http:// riberdis.cedd.net/handle/11181/4373

Murray, C. J. L. \& Lopez, A. D. (1996). The Global Burden of Disease. Summary. Interneten eskuragarri http://apps.who.int/iris/bitstream/10665/41864/1/09655 46608_eng.pdf

Olson, J. M. \& Zanna, M. P. (1993). Attitudes and Attitude Change. Annual Review of Psychology, 44, 117-154. https://doi.org/10.1146/annurev. psych.121208.131609 
OMS, O. M. de la S. (2011). Resumen Informe mundial sobre la discapacidad. Retrieved from http://who.int/disabilities/world_report/2011/summary_es.pdf

Polo Sánchez, M. T., Fernández Jiménez, C. \& Díaz Batanero, C. (2011). Estudio de la actitudes de estudiantes de Ciencias Sociales y Psicología: relevancia de la información y contacto con personas discapacitadas*. Universitas Psychologia , 10(1), 113-123. Interneten eskuragarri: http://www.scielo.org.co/pdf/ rups/v10n1/v10n1a10.pdf

Raggi, A., Leonardi, M., Covelli, V., Sattin, D., Scaratti, C., Schiavolin, S. \& Meucci, P. (2015). The ICF as a framework to collect and interpret data on the extent and variety of disability in neurological conditions. NeuroRehabilitation, 36, 17-22. https://doi.org/10.3233/NRE-141186

Rimmerman, A., Hozmi, B. \& Duvdevany, I. (2000). Contact and attitudes toward individuals with disabilities among students tutoring children with developmental disabilities. Journal of Intellectual and Developmental Disability, 25(1), 13-18. https://doi.org/http://dx.doi.org/10.1080/132697800112758

Robey, K. L., Minihan, P. M., Long-Bellil, L. M., Hahn, J. E., Reiss, J. G. \& Eddey, G. E. (2013). Teaching health care students about disability within a cultural competency context. Disability and Health Journal, 6, 271-279. https:// doi.org/10.1016/j.dhjo.2013.05.002

Satchidanand, N., Gunukula, S. K., Lam, W. Y., McGuigan, D., New, I., Symons, A. B. \& Akl, E. A. (2012). Attitudes of Healthcare Students and Professionals Toward Patients with Physical Disability. American Journal of Physical Medicine \& Rehabilitation, 91, 533-545. https://doi.org/10.1097/ PHM.0b013e3182555ea4

Shields, N., Bruder, A., Taylor, N. \& Angelo, T. (2010). Maneras de influir sobre las actitudes de estudiantes de fisioterapia en relación con adolescentes con síndrome de Down. Revista Española de Investigación E Información Sobre El Sindrome de Down, 27, 98-104. Interneten eskuragarri: http://revistadown. downcantabria.com/wp-content/uploads/2010/09/revista106_98-104.pdf

Stachura, K. \& Garven, F. (2003). Comparison of Occupational Therapy and Physiotherapy Students' Attitudes towards People with Disabilities. Physiotherapy, 89(11), 653-664. https://doi.org/10.1016/S0031-9406(05)60098-3

Stachura, K. \& Garven, F. (2007). A national survey of occupational therapy students' and physiotherapy students' attitudes to disabled people. Clinical Rehabilitation, 21, 442-449. https://doi.org/10.1177/0269215507073495

Vargo, J. W. \& Semple, J. E. (1988). Professional and Personal Attitudes of Physiotherapy Students Toward Disabled Persons. The Australian Journal of Physiotherapy, 34(1), 23-26. https://doi.org/10.1016/S0004-9514(14)60598-5

Vincent-Onabajo, G. O. \& Malgwi, W. S. (2014). Attitude of physiotherapy students in Nigeria toward persons with disability. Disability and Health Journal. https://doi.org/10.1016/j.dhjo.2014.06.009

Yazbeck, M., McVilly, K. \& R.Parmenter, T. (2004). Attitudes Toward People with Intellectual Disabilities. Journal of Disability Policy Studies, 15(2), 97-111. Interneten eskuragarri: http://journals.sagepub.com/doi/abs/10.1177/10442073040 150020401 